This item was submitted to Loughborough's Research Repository by the author.

Items in Figshare are protected by copyright, with all rights reserved, unless otherwise indicated.

\title{
Giant leaps and forgotten steps: NASA and the performance of gender
}

PLEASE CITE THE PUBLISHED VERSION

http://dx.doi.org/10.1111/j.1467-954X.2009.01822.x

\section{PUBLISHER}

Wiley-Blackwell Publishing Ltd / @ The Author and The Editorial Board of the Sociological Review

\section{VERSION}

AM (Accepted Manuscript)

LICENCE

CC BY-NC-ND 4.0

\section{REPOSITORY RECORD}

Sage, Daniel J.. 2019. "Giant Leaps and Forgotten Steps: NASA and the Performance of Gender". figshare. https://hdl.handle.net/2134/14815. 
This item was submitted to Loughborough's Institutional Repository (https://dspace.lboro.ac.uk/) by the author and is made available under the following Creative Commons Licence conditions.

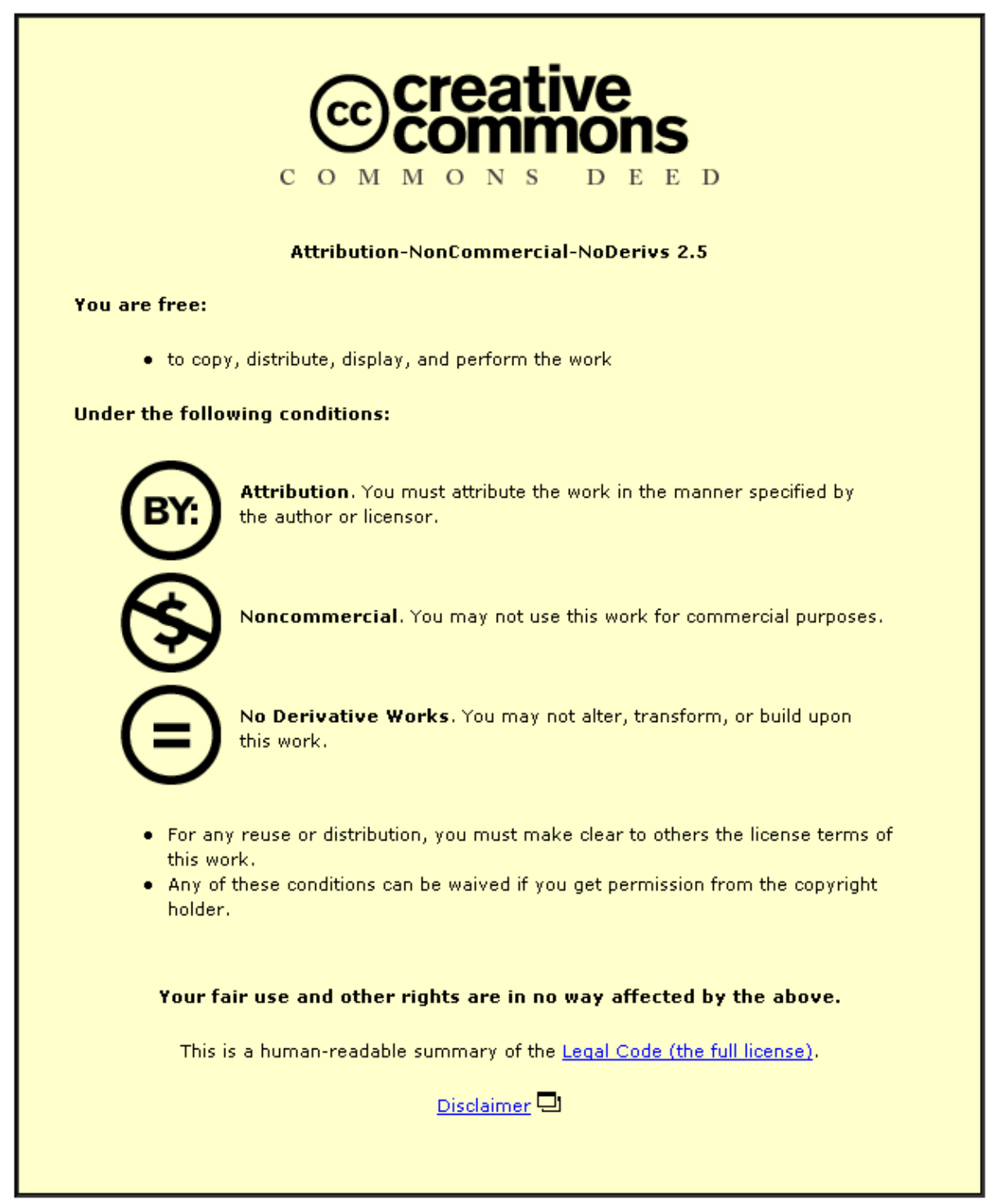

For the full text of this licence, please go to: http://creativecommons.org/licenses/by-nc-nd/2.5/ 


\section{Giant Leaps and Forgotten Steps: NASA and the performance of gender}

Popular portrayals of American spaceflight regularly propose that the history of the National Aeronautics and Space Administration epitomizes the masculinist organization of American post-WWII modernity. Films such as Philip Kaufman's The Right Stuff (and earlier book), or Ron Howard's Apollo 13, seemingly correlate the success of NASA, and by extension America and/or humanity, around the fortunes of strong, stoical, active and resourceful men. Meanwhile women such as the astronauts' wives seemingly feature as rather passive, marginalized and abjected. Manly bodies are shown here capable of 'risk taking', ‘frontier exploration', 'technical decision making', ‘competition’ and 'attention to detail', all qualities which Connell (1995) suggested typified 'hegemonic' masculinities and legitimated patriarchies. ${ }^{1}$ Popular examples of NASA's articulation of masculinist social power are complemented by various scholarly accounts explaining how NASA has historically subjugated women (Ackmann 2004; Kevles, 2003; Moule and Shayler, 2003; Penley, 1997; Weitekamp, 2004). This chapter takes the underlying claim found within such studies - NASA articulated a gendered binary - as its starting point. Rather than foregrounding the stories of women in NASA as a revisionist counterpoint, as many of these studies have, I will go further and critically assess the dis/organization of underlying binary oppositions which often frames explanations of the relationship between NASA and gender.

Focusing on the activities of NASA, particularly during the Apollo-era, I draw upon Butler's (1990, 2004) work on the performed aspects of gender and identity, to question whether and how 
NASA as an organization is complicit with the rehearsal of gendered identities through polarized binaries that align 'masculine'/'feminine' with 'male'/'female'? Butler's work provides a particularly apposite starting point to address this question, as will now be elaborated prior to the empirical discussion.

\section{Gender as performance}

In contrast to a diverse group of feminist theorists including Simone de Beauvoir, Kate Millett, Marilyn Frye or Barbara Duden, Butler rejects the idea that feminist epistemology and politics should or can differentiate a priori between identities, experiences, values or behaviors based on sexual difference (see Butler, 2004: 210-13). ${ }^{2}$ Her critique of the universalism associated with feminist theory echoes some other scholars, including Julia Kristeva, Helene Cixous and Luce Irigaray. Butler (1990), however, goes further than multiplying the category 'Woman', and questions how gender/sexual differences are performed thorough a 'heterosexual matrix': 'The heterosexualization of desire requires and institutes the production of discrete and asymmetrical oppositions between 'feminine' and 'masculine' where these are understood as excessive attributes of 'male' and 'female' (p24). She continues, '... one is one's gender to the extent that one is not the other gender, a formulation that presupposes and enforces the restriction of gender within the binary pair' (p30). Consequentially if gender is produced through binary oppositions then for Butler the 'us'/‘them' of 'masculine'/'feminine' becomes unintelligible outside of these discursive practices and desires. As Butler (1990) puts it, 'There is no gender identity behind the 
expression of gender, that identity is performatively constituted by the every 'expressions' that are said to be its results' (p41).

Importantly, Butler explains we should not abandon interest in the normative expressions of male/female binaries per se, rather we must be careful to view such 'choices' as repeated stylized acts regulated by regimes of truth (or discourses) and operationalized within institutions from the welfare state, modern medicine and perhaps also spaceflight, not part of any natural order of things (compare with Holmes, 2007; Parker, 2002) — 'To conflate the definition of gender with its normative expression is inadvertedly to reconsolidate the power of the norm to constrain the definition of gender' (Butler, 2004: 42). And so, while 'Gender is the mechanism by which notions of masculine and feminine are produced and naturalized...gender may very well be the apparatus by which such terms are deconstructed and denaturalized' (Butler, 2004: 42). Crucially for Butler the contingency and transformability of gendering binaries becomes most evident in those situations when we feel unsure of the authenticity of a gender act, hence 'Gender Trouble' (Butler, 1990). Butler's work has been of particular relevance to studies of transgender and homosexual cultures that accentuate the phantasmic construction of gender, by separating gender and biological sex, and thus challenging dominant regimes of truth around gender (cf. Parker, 2002: 152). Yet, Butler (2004) argues all gendered identities can be witnessed as phantasmic, because these 'abstract norms’ always ‘exceed the lives they make—and break’ (p56). Butler's passion for the mutability of authentic/fictional gender acts bleeds into her broader political strategy (Parker, 2002) as she seeks to concurrently describe and challenge the disciplining of modern beings through powerful regimes of truth and afford us more creativity to become (Butler, 2004: 175). 
Her celebration of transgression is however more than simply a multiplication of gendered identities, indeed as she explains, via Foucault's understanding of power, transgression from a norm can equally help refine the disciplinary techniques by which any norm is produced (Butler, 2004: 52). There are resonances here with Law's (2002) concept of fractional coherence that illustrates how postmodern reverence for multiplicity to resist modernist singularity - the modus operandi of much work on gender - often unhelpfully simplifies the nuanced practices through which gendered subjects are de/constructed.

Arguably the American space programme, especially during and before the Apollo-era, perhaps presents a rather strange association with Butler's thesis - ostensibly it is permeated with repetitive gender acts where 'authentically' masculine men are opposed to feminine women, and has become somewhat of a leitmotif for the gendering of American modernity (Penley, 1997; Weitekamp, 2004). However, in many respects such labeling only fuels the intellectual and political exigency for a more nuanced interrogation of some of the historical gendering practices surrounding space flight. Butler's approach provides a useful frame in which a historical, largely text-based, analysis of gender can mitigate a tendency to assume a priori the coherence of essentialist gender roles. My decision to focus here primarily upon encounters between women and NASA develops Butler's (1990) position that the category 'woman', articulates a conceptual fracturing of subjectivity - a fluid becoming not a fixed being (Grosz, 1994): women, as Butler (2004: 204-229) describes, are historically both inside and outside a politics based on grouprecognition and representation. ${ }^{3}$ Encounters between women and NASA can simultaneously expose and transform normative gender practices, disclosing the phantasmagoric de/construction of femininities and masculinities. Having introduced this performative approach, I will now turn 
towards three genderings within and surrounding NASA: (i) astronauts wives, (ii) women working within NASA and (iii) female astronauts.

\section{Engendering Others? : Astronauts’ wives}

Astronaut identities have ostensibly long been constructed alongside their 'Other': the seemingly supportive yet demure, passive, domestically-bound and rather abjected astronauts' wife. For example, in 1959 Life Magazine ran two covers back-to-back, depicting the original Mercury Seven astronauts and their wives: ${ }^{4}$

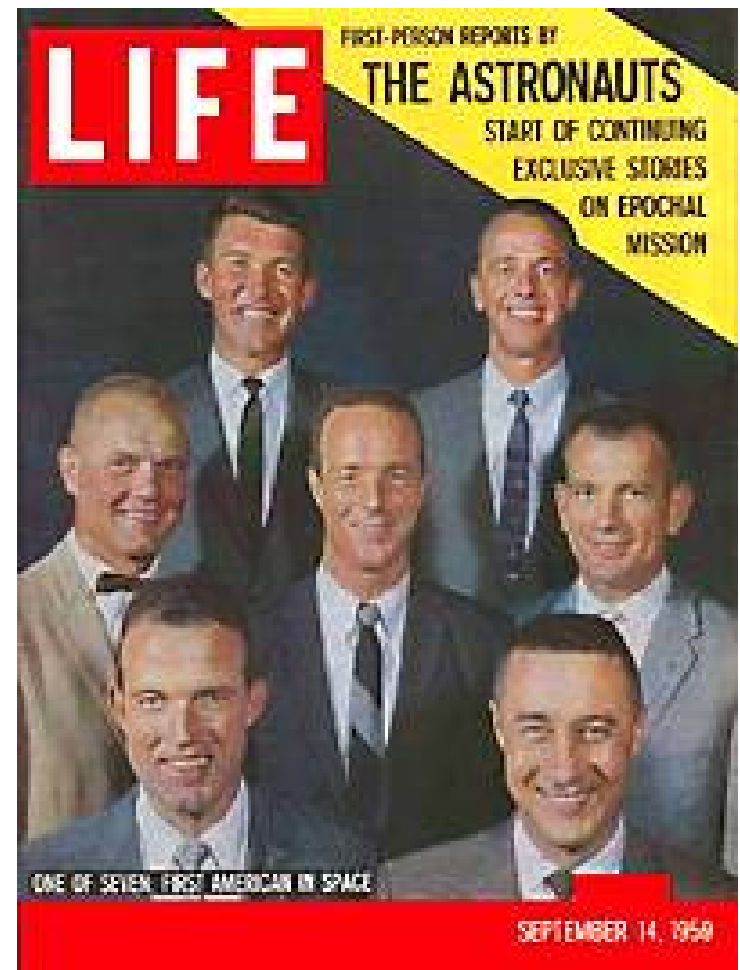


Life magazine cover September $14^{\text {th }} 1959$ (Source: Fiftiesweb, 2008)

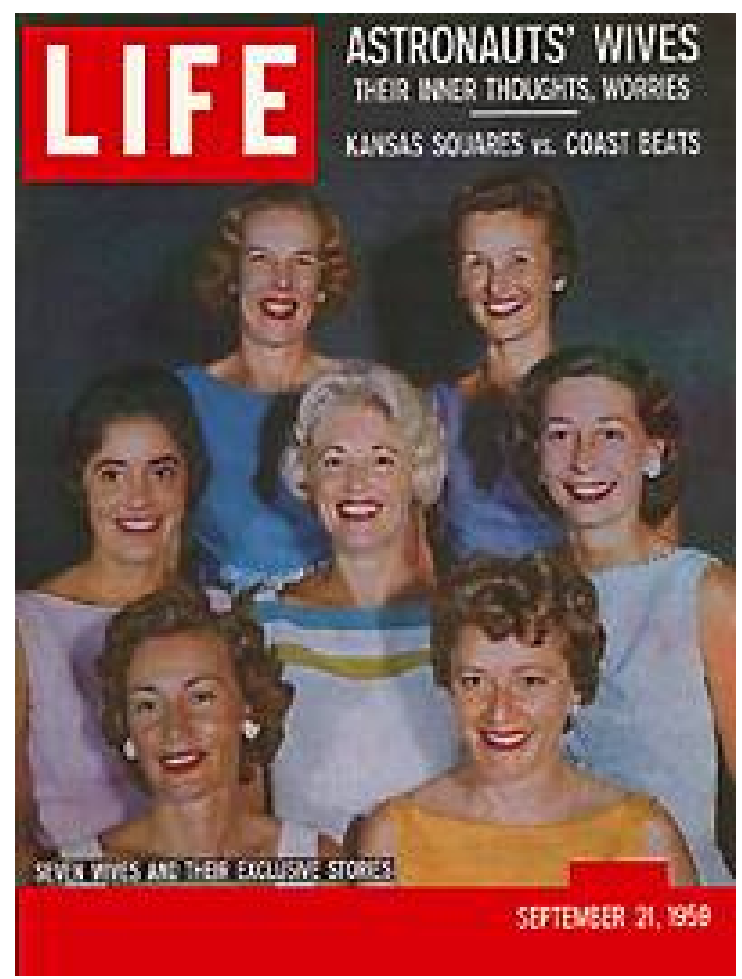

Life magazine cover. September $21^{\text {st }} 1959$ (Source: Fiftiesweb, 2008)

Here the physical contrasts between the astronauts and their wives (clothing, hair-length, jewelry and make-up) are aligned with discursive binaries between men and women as public/personal actors. For example, the men are described as part of an 'epochal mission', seemingly conjuring up images of extensive heroism, while the focus on the wives' 'inner thoughts and worries' returns us to ostensibly more 'feminine' interests. ${ }^{5}$

Similar gendered contrasts are articulated in the The Right Stuff film adaptation of Tom Wolfe's same-titled novel. In one scene, for example, the wives of prospective astronaut test-pilots are sat inside describing their anxieties about their husbands work while their husbands exemplify 
stoicism - appearing relaxed as they recall their missions around the BBQ outside. Later in the film the Mercury 7 astronauts are unveiled to the press and asked how their wives feel about their work, John Glen declares: 'My wife’s attitude towards this has been the same as it has been all along my flying career, if it's what I what to do, she’s behind it'. Meanwhile their wives, including some who had earlier expressed doubts, clap along with the gathered press crowd. Throughout the film we are presented with scenes of the wives supporting their husbands in public, despite expressing some private fears or concerns. At no point, however, do the wives appear to desire more active involvement in the space programme themselves; appearing instead content with their role as domestic supporters. Notably all the NASA employees in the film, with the exception of nurses, are portrayed by men.

Ron Howards’ Oscar-winning film Apollo 13 presents equivalent genderings. Here seemingly uncontested expressions of masculinity/femininity are essentialized in exactly the terms Butler seeks to problematize. Men appear as active agents who are strong, heroic and creative, while women - the astronauts' wives - appear as nurturing, demure and domestically bound, seeing space exploration, as a threat to this identity. In one scene, for example, Marilyn Lovell tells her husband she cannot attend his launch because their kids are busy at school. Penley (1997) captures the masculine-heroic aura of the rest of the film: 'Using only duct tape and gumption NASA teamwork turned into deliverance...[Ron Howard's Apollo 13] recreates an era when NASA appeared faultless and heroic' (p12-13). 
Despite the seeming ubiquity of gendered binaries - between public/private, active/passive, mind/body, reason/emotion, production/reproduction ex cetera - these images are often presented as performances rather than uncontested essentialisms. Indeed, in one scene The Right Stuff, one of the astronauts' wives reveals her lie to the astronaut selectors about the normative appearance of her family - at this point in the film she had decided to live away from her husband after feeling isolated. Moreover the actual astronauts' wives themselves readily acknowledge the managed nature of their identities, as Susan Borman (wife of Apollo 8 commander Frank Borman) recalls:

They had people looking into the background of the men, [and] they also had people looking into the background of the wives because they didn't want an oddball...it wasn't discussed, it wasn't written, but...you had better be in every sense of the word, the All American Family in everything you say and do!... (quoted in PBS, 2005)

Nasa wanted perfect wives, perfect children, perfect homes. There was certainly some pressure there. (quoted in Cuddon, 2007)

Tom Wolfe similarly describes his perceptions of the astronauts' wives: 'As far as the wives were concerned, their outlook was the same as that of officers' wives generally, only more so. The main thing was not to say or do anything that reflected badly upon your husband' (Wolfe, 1979: 132). As Butler (1990, 2004) suggests, normative genderings require mental and physical effort, and self-discipline to be maintained.

The Right Stuff also highlights the performativity of masculinities within NASA. In one scene, for example, the Apollo astronauts' challenge the rocket scientists' desire to perfect a fully automated space capsule and call instead for a piloted spacecraft. This scene speculates on the 
way contrasting hegemonic masculinities (Connell, 1995) - rational control versus heroic agency - are shifting and ambiguous. However it is important not to over-celebrate the presence of multiple shifting masculinities, or indeed their performativity. Following Law’s (2002) concept of fractional coherence, we might argue that while these manly identities are multiple, and even contrasting, they can still added up to a non-coherent masculine discourse that was precisely able to exclude women because it could employ multiple dominating narratives and defer its essence (compare with Connell, 2007). Or, as Law (2002) puts it: 'the singularities of the 'modern project' arise from the interferences between multiplicities produced in that characteristic oscillation between one and many' (p143). As will be shown later in this chapter, struggle with masculine narratives that legitimate patriarchy can be rendered all the more difficult not easier if that masculinity is fluid or reflectively performative, rather than singular. A deconstructive reading of masculinity is not, as Connell (2007) illustrates, enough on its own to eviscerate patriarchies.

The astronaut's wives frequently identify the media gaze surrounding the astronauts' houses as implicit confirmation of Butler's (1990) claim that the disciplinary techniques buttressing normative genderings are performative. Similarly Borman recalls, 'Some of them [the press] actually moved into the home so they could photograph us watching the launches on television. We used to call it the death watch' (see Cuddon, 2007). A comparable binarized masculinist abjection of female emotion occurred after Elliot See (prospective Gemini 9 Commander) died in a plane crash, John Young called Marilyn Lovell (wife of astronaut John Lovell) and asked her to visit See's wife. She was disbelieving: 'You want me to tell her that Elliot was killed?' Young replied, 'No. I want you to do something much harder -- not tell her. Somebody should be there 
with her right now, but she can't be told anything until I can come over and notify her officially. We don't want some overeager newspaperman knocking on her door' (quoted in PBS, 2005).

Gendered binaries were further legitimated through a discourse of rampant workaholism, as Valerida Anders (wife of Apollo astronaut Bill Anders) recalls:

You were, in effect, a single parent for the week. And when the men came home on the week-end in their T-38s [airplanes] they flew in and their first obligation was to go to the office at the Manned Spacecraft Center [Houston] and catch up on their mail, do their business at the office and then come back and spend time with the family in the time that was left of the weekend, which was generally late Saturday afternoon and all day Sunday (quoted in PBS, 2005).

Such sacrifices maintained a spatial division of labor (McDowell, 1999), that preserved a public/private (or production/reproduction) binary of masculine/feminine work. Faye Stafford (former wife of Apollo 10 astronaut Thomas Stafford), for example, describes how 'Most of us were still homemakers. I would have liked to have had a career. Especially once the children left home. It was isolating' (quoted in Cuddon, 2007). The accounts of Dotty Duke (wife of Apollo 16 astronaut Charlie Duke) are particular poignant. Duke describes how: 'Charlie was a complete workaholic. The space programme was all he thought about. I knew he would never be able to show me the love I needed or make me a priority and I became suicidal' (quoted in Cuddon, 2007).

The presence of suicidal thoughts, resistance towards the press and NASA's mission, and perhaps above all the acknowledgement of the performed, quixotic and specious 'feminine' 
identity in the 'all-American family', immediately throws into doubt not just the content but the concept of essentialized gender binaries, and indeed singular identities. Indeed often the routines of the space programme meant that wives, and indeed astronauts, ended up by necessity cultivating social roles outside of heterosexual desire. For example, the wives would frequently support each other through friendships that functioned as extended families while their husbands were away. Gracia Lousma (wife of astronaut Jack Lousma) remembers how, 'We kind of filled in for each other when the men were away. We'd have dinner together and look after each other's children'(quoted in Cuddon, 2007). Equally many of the wives were compelled to undertake domestic duties that would perhaps more normally be the responsibility of men in suburban American. Dotty Duke recalls her experiences:

...to make sure that my husband was taken care of in such a way that he could do the best job possible. I tried not to both him with mundane burdens at home. Most [astronaut] wives cut the grass, took out the garbage, and kept the house and kids in order. That was our contribution to the U.S. effort in space. (quoted in Duke, 1990)

Similarly the astronauts themselves cultivated multiple identities, such as close friendships, beyond heterosexual desire, that have endured over the decades since the Apollo program, often longer than their marriages, as illustrated in various biographies and autobiographies (Cernan and Davis, 1999; Scott and Leonov, 2004). While as Connell (2007: 146) argues such homosocial cultural practices prefigure the exclusion of women, they also promote a disarticulation of the heterosexual identities that may have initially rendered such practices legitimate. 
The self-disciplining experiences of the astronauts wives, and their representation in popular culture, initially confirms Butler's (1990) thesis that essentialized gendered binaries revolve around the performed repetition of a 'heterosexual matrix' (p6) of desire. While the possible presence of multiple, performed masculinities within NASA, as exampled above in The Right Stuff, may also serve only to police rather than alter such normative genderings. Nevertheless, the lives of these women, and indeed their husbands, reveal how they often experienced difficulty internalizing and repeating such singular identities, causing stress, anxiety and frequently embodied transformations of such prescriptive identities (Butler, 1990: 192). The next section will continue to engage with normative gendered binaries, looking at some of the experiences of women working for NASA, illustrating femininities organized through desires for creativity, technical skill and activity, not a heterosexual matrix, experiences that are notably absent from both The Right Stuff and Apollo 13.

\section{Working with the 'Other' : Women inside NASA}

During the Apollo program, many NASA employees were, as McCurdy (1993: 56-60) describes, young people, overwhelmingly men, living in hotels and motels and working long hours well into the evening and seeing their friends and family perhaps only one day a week. NASA Apollo-era management analyst Charles Bingham echoes this image as he describes how his staff at Johnson Space Center -

...had the opportunity to select very high-quality people to come work on the staff, which means that most of them were very highly self-motivated. It was not a question of people in dull, sluggish jobs, and you have to try to pump them up in order to get them to get 
away from the water cooler. It was not like that at all. Almost without exception, the people who came to work there were just charged with this emotion (Bingham, 2007).

This intensive work ethic operated as a gendering process, as it presupposed that NASA required people who would dedicate themselves solely to the space programme, exceptional people whose lives could be eulogized as beacons of the bodily regime required to organize America's exceptional destiny (McCurdy, 1993, 1997). While concluding his 1961 'Moon Landing' speech President Kennedy emphasized the character of NASA's work ethic in these terms:

It [the lunar landing] means a degree of dedication, organization and discipline which have not always characterized our research and development efforts. It means we cannot afford undue work stoppages... [he then asks that] every scientist, every engineer, every serviceman, every technician, contractor, and civil servant gives his personal pledge that this nation will move forward, with the full speed of freedom, in the exciting adventure of space (Kennedy, 1961b).

Such sentiments were frequently reiterated by NASA's senior management. For example, deputy administrator Hugh Dryden was quoted in NASA's Future Program Task Force Document (see NASA, 1965) stating: 'We must not delude ourselves or the nation with any thought that leadership in this fast-moving age can be maintained with anything less than determined, wholehearted sustained effort' (quoted in NASA 1965: 19). By conflating utopian exceptionalism with highly contingent bodily practices and work regimes, both Kennedy and Dryden presented the values which an image of a 'better' humanity would not just desire but inevitably require. 
In this manner, NASA's demarcation of the 'expert body' within the recruitment policy of 'exceptional people' tacitly constructed different bodily practices, knowledges, spacings and technologies including those in the home or even mall as somehow perhaps more 'passive', ‘ 'banal' or 'marginal' to this exciting epicenter of American modernity. Feminist scholars of technology and science provide some important insights into the dichotomous constructions of gender/technology across different spaces and times (compare with, Lerman, et al 2004). For example, Judith McGraw’s (2004) explains how in post-WWII America woman and domestic technology were mutually rendered feminine and invisible, as both were viewed as serving the basic biological functions of food, clothing or shelter, rather than as a part of a broader project of 'human creativity' or 'progress' (p32). This distinction can be readily positioned within the interlinked dualisms of public/private - active/passive - productive/reproductive and masculine/feminine spaces (see Cowan, 1976 and also, Pacey, 1999). Bettyann Kevles (2003) characterizes this division as an extension of the mapping of Cold War geopolitics into the American home, wherein 'The Soviet's promised women equal opportunities in careers like medicine and engineering; capitalists offered women consumer goods and the luxury of remaining at home to use them' (p3). Presumably for these 'capitalist women' freedom was to be equated not with equal opportunities to work but with freedom from the exhaustion of domestic work, a freedom nevertheless bound up with domestic space. And yet, as Kevles (2003) acknowledges, post-WWII labour shortages and less time-consuming domestic responsibilities as a result of household technologies, together with broader economic changes (Massey, 1994), increasingly meant that women desired and were sought after in a variety of conventionally 'masculine’ careers, including NASA. 
Unquestionably NASA was never solely a male employer. By the mid 1960s it employed thousands of women, as had its predecessor organizations such as the NACA (National Advisory Committee for Aeronautics), from seamstresses working on space suits to aerodynamics engineers and in-flight physiologists (see, Moule and Shayler, 2003: 92-107). Moreover, women were often placed in key positions of responsibility such as computing the flight trajectory for the first manned Apollo (Apollo 8) mission to orbit the Moon and return to Earth (p97). Tellingly however, in the latter case, it was a male flight controller whom was officially praised, until revisionist accounts (as in Moule and Shayler, 2003).

In a December 1961 advertisement in American Girl magazine, President Kennedy sought to encourage women to work for NASA:

In our many endeavors for a lasting peace, America's space program has a new and critical importance. The skills and imagination of our young men and women are not only welcome but urgently sought in this vital area. I know they will meet this challenge to them and to the nation with vigor and resourcefulness. (quoted in p92)

While NASA recruited women this does not automatically prohibit the organized persistence of normative gendering practices. Indeed, women had by the 1960s long contributed to American aeronautical science and engineering, especially during WWII, while binary assumptions persisted about the alignment of 'masculine'/'feminine' and 'male'/'female' work under the rubric of American progress (Keyles, 2003). Many women working for NASA during the 1960s and 1970 s testify to pervasive disciplinary and self-disciplinary techniques that articulate normative gender binaries. 
Donna Shirley recalls her experiences working as a mission engineer in NASA's Jet Propulsion laboratory during the 1960s and 70s:

Well, things are a lot better than they used to be. There's an episode in the book where my horny old boss at McDonnell Aircraft was chasing me around, a married guy, and how I finally got rid of him by subterfuge and trickery. But I don't think that the overt sexual harassment of professional women - I don't think it's quite as bad. I mean, you hear a lot more about it, but it used to be there wasn't any sense in reporting it because nobody would do anything about it so it didn't make any difference. My impression is that the really bad stuff, for the most part, is a lot better than it used to be (Shirley, 2001).

Shirley goes on remembering her accomplishments, though largely in terms of her ability to negotiate active discrimination and gender norms:

I think just being able to accomplish as much as I was able to accomplish with a lot of strikes against me, mainly being female - the aerospace industry is a cold warrior kind of industry, and it's not easy for a woman to do well in it. There are no female center directors. There's only been one, Carolyn Huntoon, and she didn't last long. Carolyn Griner was the deputy of Marshall for a long time, never became center director. Plenty of opportunities to promote her but she wasn't. There are no women AAs [Associate Administrators] in NASA except things like public relations and policy and things like that. And the same is true across the centers, there's not very many females in power positions at all, and it's very true across the whole industry. If you go to the aerospace industry, you will not see any female faces except maybe human resources. ${ }^{15}$

Tellingly perhaps Carloyn Huntoon repeats uncontested gender oppositions to articulate her experiences of gender discrimination:

There were individuals in the program that did discriminate, did make life hard for me and other women. Luckily, they moved on. I outlasted most of them. So I think the idea of women not being just like men, some people can't get over that. They would [hire] women [to] do jobs, and the fact that they didn't behave just like another guy would do meant they couldn't do the job. [Some managers] weren't willing to give them a chance 
to develop their own way of doing things. I ran into that several times. Other women have, too. It's not unique to me (Huntoon, 2002).

She continues:

But I decided that what I was accomplishing and what I was able to get done in spite of all that was worth it to me to stay there and do it, and that's why I did. A lot of women did not, would not do that. A lot of women have left, not just NASA, but other places at mid or high-level careers because they just didn't want to put up with what you had to put up with. To me, it was worth it, and, as I said, in general I was treated very well by most people. There was a few that did not, but that's life. It's not always good (Huntoon, 2002).

Feminist scholars have observed (Lerman et al, 2004) that the presence of women in such stereotypically 'masculine’ career did eventually provide a repertoire of case studies that would help feminist writers and activists later challenge the straightforward alignment of 'masculine'/'feminine' with 'male'/'female'.

Given such experiences within NASA it is perhaps not surprising to find how Charles Bingham, who once worked for NASA human resource development at Houston, expressed the pessimism felt by women (and ethnic minorities) towards employment in NASA during the Apollo-era:

If you know NASA at all, you know this is not where women and minorities would normally turn as a first opportunity for a job. At that time [during Apollo] particularly even with the best women in the world, there were not that many women taking advanced engineering programs. That's not to say that they were not out there, but it is to say that you had to work harder to go find them or to make the fact known that Houston was a good place for women and minorities to work. A lot of them didn't believe it. A lot of them didn't believe that you could go into an old-fashioned engineering shop and ever be given any responsibility or become a real partner in the organization (Bingham, 2000). 
It is important to note that while normative gendered binaries continue to be performed within NASA into the twenty first century (even in the accounts of women previously suffering from such narrow identity prescriptions), the enduring passion and skill with which many women invested themselves in spaceflight subverts many gender essentialisms, not least the premise that womanly and manly desires can only be understood through a neat hetero-sexual matrix of oppositions (Butler, 1990). Indeed, as Butler (2004) suggests it is inaccurate to equate any measure of institutional identity with either strictly masculine or feminine identities, values or behaviors. Rather we should describe the on-going dis/organzaition of normative gender practices, and foreground those moments - as Carolyn Huntoon's account might example - when the easy mapping of concepts of gender and sexual difference onto organizational and technical efficacy becomes problematic. The next section develops this line of thinking about transgressive desires and bodily competences by attending to a set of bodies that offered potentialities to throw into relief perhaps one of the most popularly understood 'masculine' technical environments: the spacecraft.

\section{Risky bodies? : The Lovelace Women in Space Project}

The masculine self-identity of pilots has often been understood through an eroticized desire for risk and suffering, or what Law (2002) terms 'Thrills and spills' (p32). Similarly, McCurdy (1993), quotes one Apollo astronaut as saying, 'Recognition of risk is what made us as good as we were' (p62), while another states 'But if it [risk of death] was like, one in one hundred, you would do it, you take it...There were so many ways it could happen' (p63). Across such 
statements astronauts' fetishized tolerance of risk as a part of the performance of manliness; risk became part of the astronauts' identity, contributing to what Tom Wolfe's novel (1979) famously referred to as 'The Right Stuff'. Yet this attitude towards physical and mental subjugation was not mere blind masochism; it was, also predicated upon a set of techniques concerned with the control of bodies wherein the astronauts were rigorously tested to confirm a high degree of corporeal control and calculation over their own bodies and perform tasks in this hostile environment - to maintain control in a situation despite the discomfort and vulnerability and get the job done.

Within all these images of the astronaut there exist mutually shaping essentializing associations between masculinity, corporeality, outer space, risk and high-technology that prefigure the identity construction of 'The Right Stuff'; becoming increasingly evident when challenged with transgressive Other(s), namely female bodies. ${ }^{6}$ Such an instance occurred in 1962, when a small group of women successfully passed the some of same physical and psychological tests as the Mercury astronauts, in a privately funded women astronaut study organized by a physiologist called Dr. William Lovelace (see, Shayler and Moule, 2003; Weitekamp, 2004). The women now sought NASA's support to become astronauts. 'Lovelace's Women in Space Project' (Weitekamp, 2004) or 'The Mercury 13' (Ackmann, 2004) de-stabilized many of the iterative bodily performances enacted through NASA that prescribed binary gendered assumptions. ${ }^{7}$ The desire of these women to become astronauts and their embodied suitability, transgressed the tacitly masculinist spatio-temporal categorization of different bodies under modernity (Massey, 2005: 93). 
These bodies offered, in Judith Butler's (1990) terms, a sense of hope 'in the possibility of a failure to repeat, a de-formity, or a parodic repetition that exposes the phantasmatic effect of abiding identity as a politically tenuous construction' (p192). Just as some homosexual bodily performances may present a particular body in an opposing gender role (see Butler, 1990: 16770), thus exposing the de-stabilized 'ground' of both gendered identities, these astronauts tacitly desired to place a female body in a hegemonically masculine guise. Yet equally, as Butler (1990) makes clear, such transgressions, while sometimes transformative, are frequently accompanied by 'punishments that attend not agreeing to believe in them' (p190). For example, in 1962 Dr. Lovelace sought the Navy's permission to expand his use of their facilities to provide further evidence of the women's suitability. The official reply to the Navy was that 'NASA does not at this time have a requirement for such a program' (Weitekamp, 2004: 128). This reply was then made know to Dr. Lovelace and the women involved; it effectively cancelled the nascent woman into space project. Here, the twin spectres of technological determinism and instrumentalism (Feenberg, 1999) are used to conjure up a belief in value-neutral, automatic and unilateral technical decision-making as driving forwards the space programme. In turn, this meant that the space programme could be constructed as if it were an inevitable temporal sequence, expressing natural gender roles and bodily practices, and devoid of ethno-political import (Shayler and Moule, 2003).

The decision was re-examined in a heated Congressional hearing in July 1962, in which the Lovelace Women, led by Geraldine 'Jerrie’ Cobb, were cross-examined by Congressmen partly 
in an attempt to objectively illustrate their technical worth above and beyond their male peers (Shayler and Moule, 2003, p149). The women demonstrated the capacity of their bodies to pass the same flight-tests as men, as well as possessing some important advantages, not least their requirements for less food and oxygen — on account of their smaller size (Penley, 1997: 55). Ultimately, however, the women's transgressive bodily desires were blocked through quasijudicial significations of risk. Namely, a belief asserted by NASA that astronauts had to be jettest pilots, a profession women were already barred from, because only jet test pilots possessed the necessary experience to undertake high-risk flight experiments. This point appeared already undermined by NASA's own demonstration that spacecraft could fly automatically in outer space (Penley, 1996), combined with the rejection of many skilled test-pilots by the astronaut programme, such as Chuck Yeager. NASA's Chief of Manned Space Flight, George Low, then explained to Congress how NASA support for the women-in-space project would setback his work, despite the fact that Lovelace had requested the very limited use of Navy not NASA facilities (Ackmann, 2004: 166). More implicitly, it appears the decision revolved around a belief that women were excluded from becoming jet test pilots (or astronauts) because it was deemed too risky (Weitekamp, 2004: 149). In this case, a masculinized relationship between technology and risk within American modernity proved intractable; accordingly men were able to dictate thresholds of female risk. As Weitekamp's (2004) explains the male construction of female risk prevalent in NASA was two-fold: on the one hand, NASA seemed reluctant to subject women to degrees of risk because 'the prospect of subjecting a woman to mortal danger betrayed the rigidly defined gendered roles asserted in post-war America' (p3). On the other hand, this paternalist designation of women as needing protecting might itself lead the public to conclude that if women flew in spacecraft then the crafts themselves might be deemed too straightforward 
and safe. Thus as Weitkampf (2004) puts it, if 'a woman could perform those tasks [it] would diminish their prestige’ (p3).

The appropriation within NASA of risk as the legitimate means by which to exclude women from outer space appears only strengthened through its seemingly contradictory blending of different masculine identities. In this case, risk is alternately, and seemingly paradoxically, constructed as both a cipher for the rational management of hazards and the manly celebration of danger. Here the capacity to render masculinity fractionally coherent (Law, 2002) renders it more not less persistent in justifying patriarchal norms.

The Mercury astronaut John Glenn, who had just returned back to Earth to a ticker-tape parade after being the first American to orbit the Earth, summarized his verdict in a final statement within the hearing:

I think this gets back to the way our social order is organized really. It is just a fact. The men go off and fight the wars and fly airplanes and come back and help design and build and test them. The fact that women are not in this field is a fact of our social order. It may be undesirable (quoted in Weitekamp, 2004: 151).

While Glenn's reference to ‘undesirable’ may be telling of shifting attitudes towards women, he nevertheless asserts that there is something inherently masculine about these interactions between bodies, risk and technology, so that only particular bodies were deemed not just more 
desirable but almost factually suitable. After the hearing, female astronauts were frequently the subject of further derision, often evoking the 'heterosexual matrix' of submissive female sexuality, as Wernher von Braun demonstrated in a speech given at Mississippi State College (19/11/1962):

Well, all I can say is that the male astronauts are all for it. And as my best friend Bob Gilruth [director of Johnston Space Center of manned spaceflight] says, we're reserving 110 pounds of payload for recreational equipment (from Parade Magazine Sunday Supplement, December 1962 - quoted in Kevles, 2003: 4).

Harry Hess, a Princeton Professor and Chair of the Space Studies Board at the National Academy of Sciences, adopted a similar approach to explain away female astronauts by stating unequivocally that 'leaving the kids behind was not part of womanhood's idealized image' (quoted in Kevles, 2003: 47).

Ultimately, as Weitekamp (2004) surmised of the Apollo era: 'NASA had no room in its mission objectivities for acting as an agent of social change' (p157). Indeed it was not until 1978, and the development of the shuttle programme, that NASA would select women as astronauts. ${ }^{8}$ By this point frontier analogies were being drawn upon to retrospectively excuse the omission of women from past astronaut selections; NASA's media rhetoric talked of the shift from explorers to pioneers, or from surveyors to homesteaders (Kevles, 2003: 56). Making a similar nod to spatialized gender roles, Carolyn Huntoon, describes what she saw as the reasons behind the new policy for astronaut selections to the space shuttle: 'It was going to have more space in it for the 
crews. It was going to have some of the conveniences of home that previous space capsules had not had. And the laws were changing in our country that women could no longer be discriminated against. The decision was made that we would select qualified women to fly in space'. Again the domestication of space missions appears to go hand in hand with the presence of women in outer space. In both cases, stereotypical gender roles, frequently made through a gendered (mis)reading of American frontier expansion in the nineteenth century, provided an illfitting though seemingly seductive temporal analogy to explain away almost thirty years of institutionally prejudicial accounts of bodily difference and space exploration. This re-telling of a spatial division of labor, as a teleological sequence, where male explorers precede female pioneers, reveals the way prescriptive bodily performances were retrospectively legitimated within a heterosexual matrix, even by women themselves.

Eventually in 1983, over thirty years after the Lovelace women's plight, Sally Ride would become the first American female astronaut to fly into space (Penley, 1997: 55); though not until Eileen Collins in 1999, over 40 years since its founding would NASA give a women the opportunity of commanding a spacecraft (p13). ${ }^{9}$ As Kevles (2003) optimistically puts it, 'women can now decide risks for themselves' (p56), while many more women are entering science and engineering disciplines and training to be pilots. Even so, only $10 \%$ of astronauts being selected are women, as Carolyn Huntoon reports, perhaps the institutionalized desire to uphold this assemblage of American modernity as a male domain are changing, albeit slowly. 


\section{Concluding comments}

Across these varied sources, from films to oral histories, I have sought to render visible some of the performances surrounding the dis/organization of gendered identities within NASA. Just as Butler (1990) proposes my methodological choices are manifestly also my political strategy. I have focused on those moments within and surrounding NASA where gender roles became disengaged from a straightforward alignment with biological sex. My intention here has been to reveal the lived circumstances and embodied practices through which totalizing gender discourses are enacted. Following Butler (1990), I have focused on the way embodied performances, from grass-cutting to astronaut testing, inscribe and transform normative binaries. My reading of NASA is, of course, partial, developed from a particular theoretical stance towards gender, combined with three extended, though unavoidably limited, slices of NASA history. I have sought to foreground how a diverse set of statements concerning gender, implicitly perform the gendered subjects they were explicitly trying to represent. The elision of the performativity of gender, which is perhaps best exampled by John Glenn's reference to the social factuality of gender roles, both obscures and reinforces its normative power-effects. My focus upon women and NASA, while in keeping with Butler's (2004) own understanding of women as a necessary aspect of treating gender as a 'becoming', has ostensibly downplayed some of the multiple masculinities within NASA. However, as the tensions between the Mercury 7 astronauts and rocket scientists' near the start of this chapter reveal, as well as NASA's use of a non-coherent concept of risk in the 'Lovelace' hearing, I suggest that multiplying gendered identities, whether male or female, does not necessarily help expose and challenge its normative 
power-effects. Put more formally, perhaps it is problematic to valorize 'Self' multiplicity, and then risk overlooking the way multiplicity, can sometimes subjugate that which appears 'Other'.

This reading of the experiences of women within NASA illustrates the sacrifice and cost for women who failed to repeat a recognizable gendered identity, yet perhaps equally it provides a great deal of potentiality to rethink the prevalent reading of NASA, particularly during the Apollo-era, as an uncontested masculinist realm. As Judith Butler (1990) maintains gendered identities must be constantly performed, hence are capable of being otherwise. While the accounts of Carolyn Huntoon testify how NASA, and in particular the human spaceflight programme, continues to remain a male-dominated institution it is perhaps encouraging to note here the many embodied examples - from Dotty Duke’s lawnmowing to female rocket trajectory programmers and Geraldine Cobb’s 'expert' body - where binary categorization, prejudice and discrimination only fuelled, and indeed frequently necessitated, transgression of prescriptive and oppressive gendered identities.

\section{Notes}

${ }^{1}$ The phrase 'hegemonic masculinity' was first coined by R.W.Connell in the book Masculinities (see Connell, 1995). Connell's thesis is that masculinities are intentionally constructed from a repertoire of choices, never given a priori, and are therefore capable of being multiple. Connell identifies a series of normative traits associated with men, such as risk-taking, physical prowess, competitiveness, domination, logic and control, which have all been historically used to justify the subordination of women.

${ }^{2}$ The assumption of a natural opposition between universalized male and female experienced can also be found in some writing on masculinity (see for example Connell, 1995). 
${ }^{3}$ The concept of becoming is developed by Butler (2004) through her reading of Deleuze and Guattari's concept of 'becoming-women'. Deleuze and Guattari (1987) explain, 'It is perhaps the special situation of women in relation to the man-standard that accounts for the fact that becomings, being minoritian, always pass through a becoming-women' (p291). While the manstandard reifies dualisms, a becoming 'has neither beginning nor end, departure nor arrival, origin nor destination...A becoming is neither one nor two, nor the relation of the two; it is the in-between' (p293). Hence if a man escapes such dualisms and identification, he must also pass through a becoming-women on the way to 'becoming-imperceptible'.

${ }^{4}$ Notably part of the contract with Life magazine meant that the astronauts would be protected by a life assurance policy and that the family would receive a stipend from the magazine. Hence despite the growing funding for the early space programme, NASA perhaps reflected a patriarchal bias that disconnects public and private spheres: work and home (see: http://www.pbs.org/wgbh/amex/moon/peopleevents/p_wives.html April 2nd 2008)

${ }^{5}$ Heroism is frequently associated with masculinities. Perhaps the best way to think about this is in terms of a sense of subjective autonomy - an exaggerated sovereign agency - capable of thinking and acting independently of external relations. Here heroism suggests the apotheosis of a mind/body dualism - the marginalization of the mind-body and a God-like aggrandization of a dispassionate mind (compare with Haraway, 1991).

${ }^{6}$ The bodies of animals, in particular chimpanzees, similarly illustrate masculinist assumptions surrounding NASA. Indeed chimpanzees were used in the early days of the space programme to test the effects of weightlessness for later human astronauts. While the presence and competence of such passive explorers might seem to challenge masculine identities based on heroic action, as Haraway (2004: 93-95) explains their role is actually more complicit with masculine identities than might be suspected. They were, as she puts it, 'neonates, born of the interface of the dreams about a technisist automaton and masculinist autonomy' (p94). Or, in other words, they were repressed subjects whose symbiotic relations with telemetric technology made them appear fully controllable, predictable and ordered, all under the watchful gaze of man (for further discussion on NASA and animals, see Gray, 1998).

${ }^{7}$ As Weitekamp explains (2004: 192) it is perhaps inappropriate to refer to the women as the 'Mercury 13', because they had no formal connection with NASA or the 'Mercury 7'. And moreover the women never met each other, or knew each other, as a single group.

${ }^{8}$ During the period before 1978, steps towards eradicating essentialist gender roles in NASA's selection process had been slow. For instance, two 'Lovelace' scientists in the mid 1960s recanted on their early work and testified to NASA that female astronauts were prone to be more 
'emotionally unstable' supported by 'unspecified studies of menstrual women' (Kevles, 2003: 13). This study is lamented by Kevles (2003: 13), principally because of its tautological logic that because there were no female astronauts in NASA then why would further research be required to disprove such prejudicial accounts of bodily difference.

${ }^{9}$ In a rather explicit act of NASA criticism, on her first launch into space Eileen Collins invited all the surviving 'Lovelace' women and even carried mementos with her into orbit from these women (see Penley, 1997: 89).

\section{References}

Ackman, M (2004), The Mercury 13: The True Story of Thirteen Women and the Dream of Space Flight, New York: Random House.

Bingham, C (2000), Interview with Butler. C., Johnston Space Center Oral History Project, 9 April, Available at:

http://www.jsc.nasa.gov/history/oral_histories/a-b.

[Accessed 25/3/08]

Butler, J (1990), Gender Trouble, London: Routledge.

Butler, J (2004), Undoing Gender, London: Routledge.

Cuddon, S (2007) The Astronaut Wives' Club, BBC News, [internet], 8 November. Available at: 
http://news.bbc.co.uk/1/hi/magazine/7085003.stm, [Accessed 12/7/08]

Cernan, E and Davis, D (1999), The Last Man on The Moon, New York: St Martin’s Griffin:

Connell, R, W (1995), Masculinities, Berkley, CA: University of California Press.

Connell, R, W (2007), 'Masculinities, Power and Alliance Politics', in Ashe, F. (ed), The New Politics of Masculinity: Men, Power and Resistance, London: Routledge.

Cowan, R. S (1976), 'Two Washes in the Morning and a Bridge Party at Night: The American Housewife Between the Wars’, Women's Studies, 3(2), 147-172.

Deleuze, G. and Guattari, F (1987), A Thousand Plateaus: Capitalism and Schizophrenia, London: Continuum.

Duke, C (1990), Moonwalker, Nashville, TN: Thomas Nelson Inc.

Feenberg, A. (1999), Questioning Technology, London: Routledge.

Fiftiesweb (2008) Index Fiftiesweb, [online]

http://www.fiftiesweb.com/

[Accessed 12/8/08]

Gray, T (1998), A Brief History of Animals in Space, [internet] Washington D.C.: NASA History Office.

Available at:

http://history.nasa.gov/animals.html [Accessed 15/6/08]

Grosz, E (1994), Volatile Bodies: Toward a Corporeal Feminism, Indiana: University Press. 
Haraway, D, J (1991), Simians, Cyborgs, and Women: The Reinvention of Nature, London: Free Association Books.

Haraway, D, J (2004), The Haraway Reader, London: Routledge.

Holmes, M (2007), What is Gender?, London: Sage.

Huntoon, C (2002) Interview with Butler, C., Johnston Space Center Oral History Project, 5 June, Available at:

http://www.jsc.nasa.gov/history/oral_histories/herstory.htm

[Accessed 3/4/08]

Kennedy, J, F (1961) Special Message to the Congress on Urgent National Needs, In Joint Session of Congress, Washington D.C. May 25th, 1961. Available at:

http://www.jfklibrary.org/Historical+Resources/Archives/Reference+Desk/Speeches/JFK/003PO F03NationalNeeds05251961.htm. [Accessed 12/6/08]

Kevles, B. H (2003), Almost Heaven the Story of Women in Space, Jackson TN: Basic Books.

Law, J (2002), Aircraft Stories: Decentering the Object in Technoscience, Durham, NC: Duke University Press.

Lernan, N. E. Oldenziel, R. and Mohun, A. P. (eds.), (2004), Gender and Technology: A Reader, Baltimore: John Hopkins University Press.

Massey, D (1994), Space, Place and Gender, Oxford: Blackwell.

Massey, D (2005), For Space. London: Sage. 
McCurdy, H. E (1993), Inside NASA: High Technology and Organizational Chance in the U.S. Space Program. Baltimore, MD: John Hopkins University Press.

McCurdy, H. E (1997), Space and the American Imagination, Washington D.C.: Smithsonian Institution Press.

McDowell, L (1999), Gender, Identity and Place: Understanding Feminist Geographies, Cambridge: Polity Press.

McDougall, W. A (1985), A Political History of the Space Age, Baltimore, MD: John Hopkins University Press.

McGraw, J, A (2004), Why Feminine Technologies Matter. In Lernan, N. E. Oldenziel, R. and Mohun, A. P. (eds.) Gender and Technology: A Reader, John Hopkins University Press: Baltimore.

NASA (1965), Summary Report: Future Program Task Group. In Logsdon, J. et al (eds.) (1995) NASA and the Exploration of Space, Volume 1. Washington D.C.: NASA History Office .

Pacey, A (1999) Meaning in Technology, Cambridge, Mass: MIT Press.

Parker, M (2002), 'Queering Management and Organization', Gender, Work and Organization, 6,(2), 146-166.

PBS (2005), NASA Wives and Families, Public Broadcasting Service [online]

Available at:

http://www.pbs.org/wgbh/amex/moon/peopleevents/p_wives.html [Accessed 12/4/08]

Penley, C (1997), NASA/Trek: Popular Science and Sex in America, London: Verso. 
Scott, D and Leonov, A (2004), Two Sides of the Moon: Our Story of the Cold War Space Race, London: Simon Schuster.

Shayler, D. J and Moule, I. A (2003), Women in Space - Following Valentina, New York: Springer.

Shirely, D (2001), Interview with Butler. C., Johnston Space Center Oral History Project, 17 July, Available at:

http://www.jsc.nasa.gov/history/oral_histories/herstory.htm

[Accessed 12/3/08]

Weitekamp, M. A (2004), Right Stuff, Wrong Sex: America's First Women, Baltimore, MD: Johns Hopkins University Press.

Whitehead, S and Barret, F (2001), Masculinities Reader, Cambridge: Polity Press.

Wolfe, T (1979), The Right Stuff, London: Bantam Press. 